\title{
21. CLAY FABRIC DEVELOPMENT IN A DEEP-SEA CORE: SITE 515, DEEP SEA DRILLING PROJECT LEG 721
}

\author{
Richard W. Faas and David S. Crocket, Lafayette College, Easton, Pennsylvania
}

\begin{abstract}
Hole 515A was drilled in the southern Brazil Basin by the Glomar Challenger on DSDP Leg 72, using the newly developed hydraulic piston corer (HPC). A total of $108 \mathrm{~m}$ of undisturbed terrigenous mud (T1) and sandy mud (T2) was obtained (see site chapter, Site 515, this volume). The core was sampled at levels that corresponded to 50-kPa increments of overburden pressure to determine if a pattern of clay fabric development could be discerned. After criticalpoint drying and gold-palladium coating, 15 samples were analyzed with a scanning electron microscope (SEM).

Clay fabric consists of randomly oriented, large and small domains of face-to-face (FF) stacked clay particles, frequently linked together by short "chains" in an edge-to-face (EF) orientation. As overburden pressure increases, linkages decrease, and the "chains" become incorporated into the domains. Distortion of platelike domains into "cornflake" structures (well-crystallized montmorillonite?) and spherical aggregates occurs at overburden pressures of 400 $\mathrm{kPa}$. Orientation parallel with bedding occurs at $500 \mathrm{kPa}$ as the "cornflake" structures become flattened and compressed. Maximum fabric development occurs at $590 \mathrm{kPa}$. Large plates and coalesced domains form a pervasive linear FF pattern, interrupted by a few large and small EF bridging structures. Deformation of the large EF-oriented plates occurs, forming circular, pitlike voids.

Fabric development in cores from this deep-sea site follows well the developmental model suggested by Bennett and others (1981) for Mississippi Delta clays with high to medium void ratios.
\end{abstract}

\section{INTRODUCTION}

The process whereby newly deposited sediment particles gradually become lithified under increasing overburden pressure is called "gravitational compaction" (Hedberg, 1936). The process consists of three stages: (1) the mechanical rearrangement and dewatering stage in which porosity is reduced from $90 \%$ to $35 \%$; (2) the mechanical deformation stage in which porosity is reduced from $35 \%$ to $10 \%$; and (3) the recrystallization stage, where porosity is less than $10 \%$ and the main mechanism is recrystallization under high pressures.

Weller (1959) proposed a similar compaction model for sediments having an initial porosity from $85 \%$ to $45 \%$. Under increasing overburden pressure, interstitial fluids are expelled, with porosity decreasing to $10 \%$. Associated with this is a rearrangement of mineral grains and a development of closer packing, related to the yielding of the clay minerals between the more resistant grains.

In this contribution, we are concerned with the response of a deep-sea sedimentary section composed of terrigenous clay to the process of reduction of the initial porosity from $85 \%$ to $58 \%$ under overburden pressures gradually increasing to $590 \mathrm{kPa}$. In particular, we examine the microstructural changes of the clay particles, including particle rearrangement and particle-packing relationships. In addition, we are interested in determining if early diagenesis may be occurring at porosities greater than $10 \%$.

\section{STUDY MATERIAL AND ANALYTICAL PROCEDURE}

DSDP Leg 72 provided us with an opportunity to study the early aspects of the compaction process. During that voyage, the newly de-

${ }^{1}$ Barker, P. F., Carlson, R. L., Johnson, D. A., et al., Init. Repts. DSDP, 72: Washington (U.S. Govt. Printing Office). veloped hydraulic piston corer (HPC) was used and a number of high quality, essentially undisturbed cores were obtained from the southern Brazil Basin, about $200 \mathrm{~km}$ north of the northern exit of the Vema Channel (Fig. 1). At Hole 515A, the HPC recovered $108 \mathrm{~m}$ of undisturbed sediment, providing the samples for our study. The sediment is a grayish brown terrigenous mud with occasional nannofossil-rich layers and some foraminifer-rich layers. Clay content is high ( $55 \%)$, with quartz plus feldspar $(10 \%)$, pyrite and micronodules $(2 \%)$, heavy minerals $(2 \%)$, and mica $(1 \%)$. The average texture is $3 \%$ sand, $20 \%$ silt, and $77 \%$ clay. Onboard X-ray diffractograms indicated that montmorillonite, illite, and phillipsite are the prevailing clay minerals (see Coulbourn, this volume).

Our intention was to study development of the clay fabric under increasing increments of overburden pressure using the ISI Super IIIA scanning electron microscope at Lafayette College. This instrument is equipped with a Princeton Gamma Tech System III microanalysis system enabling us to identify semiquantitatively the elements present in each sample.

Cores from Hole $515 \mathrm{~A}$ were sampled at $50-\mathrm{kPa}$ intervals where possible (Samples 515A-1-1, 105-107 cm, and 515A-2-2, 31-33 cm, were taken at 10 and $25 \mathrm{kPa}$, respectively). A $30-\mathrm{cm}^{3}$ cylinder was pressed into the split half of the core, extracted, and sealed in a polyethelene container until analyzed. All samples were oriented according to the long axis of the core.

A sample was trimmed from the cylinder with a sharp knife producing a wafer of approximately 2 -mm thickness (Fig. 2). The wafer was scored parallel to the horizontal plane, then pulled apart along this plane and trimmed. The trimmed sample was carefully transferred to an evaporating dish maintaining its orientation. It was then washed successively with $70 \%, 80 \%, 90 \%$, and then absolute ethanol, testing for complete removal of $\mathrm{Cl}^{-}$using silver nitrate solution. A portion of the sample was then carefully cemented on an aluminum stub using carbon paint, critical-point dried using liquid carbon dioxide (Bennett et al., 1979), and lightly gold-coated. This provided an undisturbed surface of a plane parallel to the horizontal (see Fig. 2).

\section{BACKGROUND}

Over the past decade, interest has been shown in the configuration and orientation of clay particles of sediments accumulating in various types of sedimentary environments. Earlier studies using the transmission electron microscope (TEM) showed that marine clay parti- 


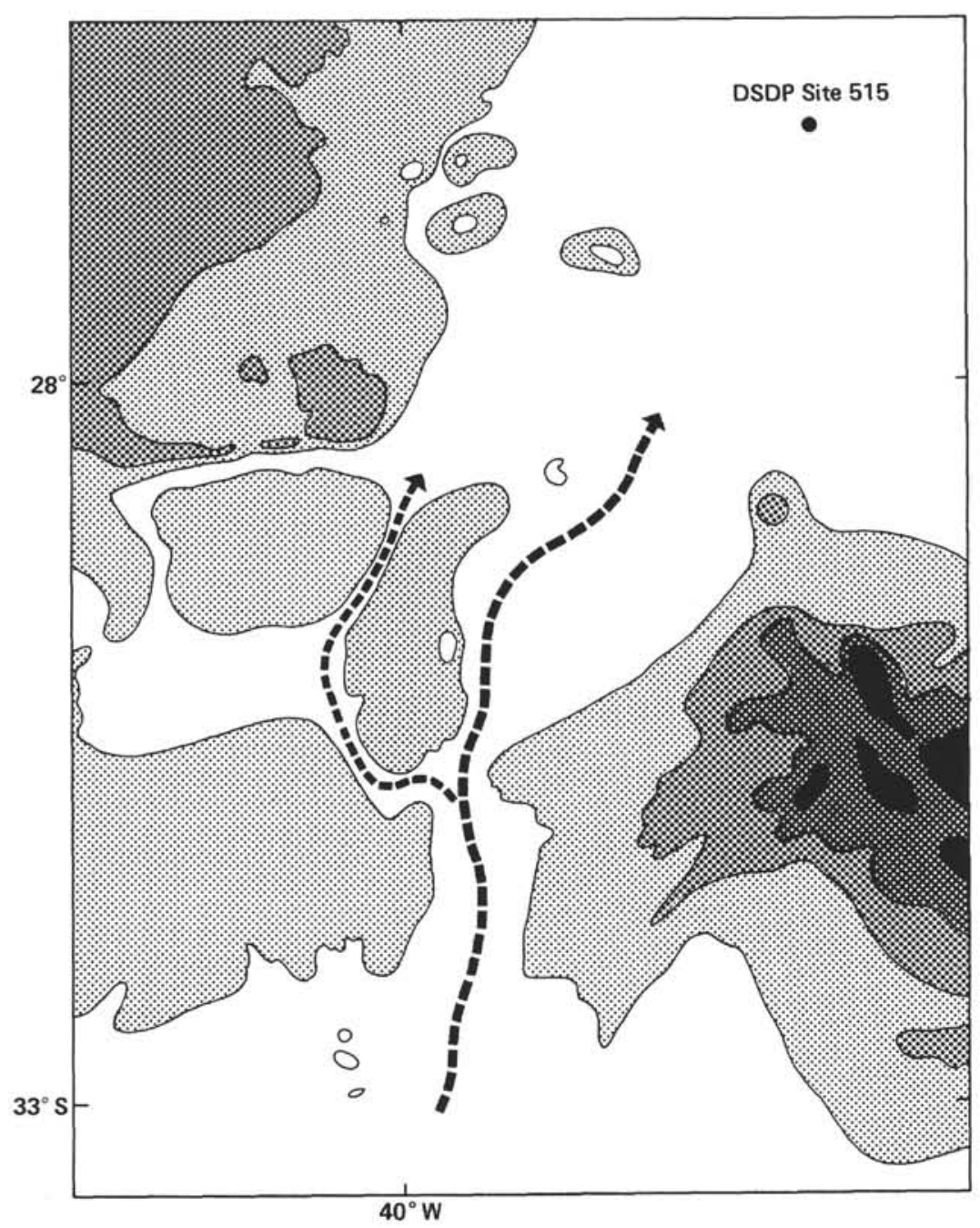

Figure 1. DSDP Site 515 and bottom water paths through Vema Channel.

cles form a fabric with a three-dimensional configuration, dominated by contacts between corners and planes of mineral particles (Rosenquist, 1959). Other studies (Brewer and Haldans, 1957) indicated that the presence of silt and sand particles influences the overall arrangement of the clay particles in close proximity to the larger grains.

Several attempts to describe fabric and fabric changes under various degrees of loading through consolidation testing have been made. Bowles, Bryant, and Wallin (1969) took sediment samples with high void ratios from the Gulf of Mexico and consolidated them in the laboratory to overburden pressures of $6276.3 \mathrm{kPa}\left(64 \mathrm{~kg} / \mathrm{cm}^{2}\right)$. They showed that microstructural changes became significant at the relatively low overburden pressure of $\mathbf{3 9 2 . 3}$ $\mathrm{kPa}\left(4.0 \mathrm{~kg} / \mathrm{cm}^{2}\right)$; strong preferred particle orientation occurred at greater pressures. Bryant, Deflache, and Trabant (1974), in commenting on the earlier work by Bowles and others (1969), suggest that the strongly preferred orientation demonstrated under a $6276.3-\mathrm{kPa}(64.0-$ $\mathrm{kg} / \mathrm{cm}^{2}$ ) load may be an artifact associated with consolidation testing and may not reflect the natural compaction process occurring in the marine environment.
Bennett, Bryant, and Keller (1981) relate the clay fabric of selected Mississippi Delta sediment and equatorial Pacific red clay to selected geotechnical properties and depth of burial. They suggest that in smectitic/illitic clays, fabric development is linked to reduction of void ratio (e). Sediments with very high void ratios $(e>3.0)$ have a fabric dominated by "single platelike particles and chains"; sediments with high void ratios (e > 2.5) are dominated by "domain particles and chains." More domains and shorter chain length occur in sediments with medium ( $\mathrm{e}=2.5$ to 1.5$)$ and low $(\mathrm{e}<1.5)$ void ratios; parallel orientation of domains (perpendicular to overburden stress) occurs in sediments with very low void ratios $(\mathrm{e}<1.2)$.

\section{DATA ANALYSIS}

Our research attempts to analyze the regular development of clay fabric in a submarine core under conditions of normal compaction (i.e., pore pressure is hydrostatic at all depths). Conditions of overcompaction or undercompaction would likely show pore pressure differences (Bohlke and Bennett, 1980), which would interrupt the regularity of fabric development. Compaction 


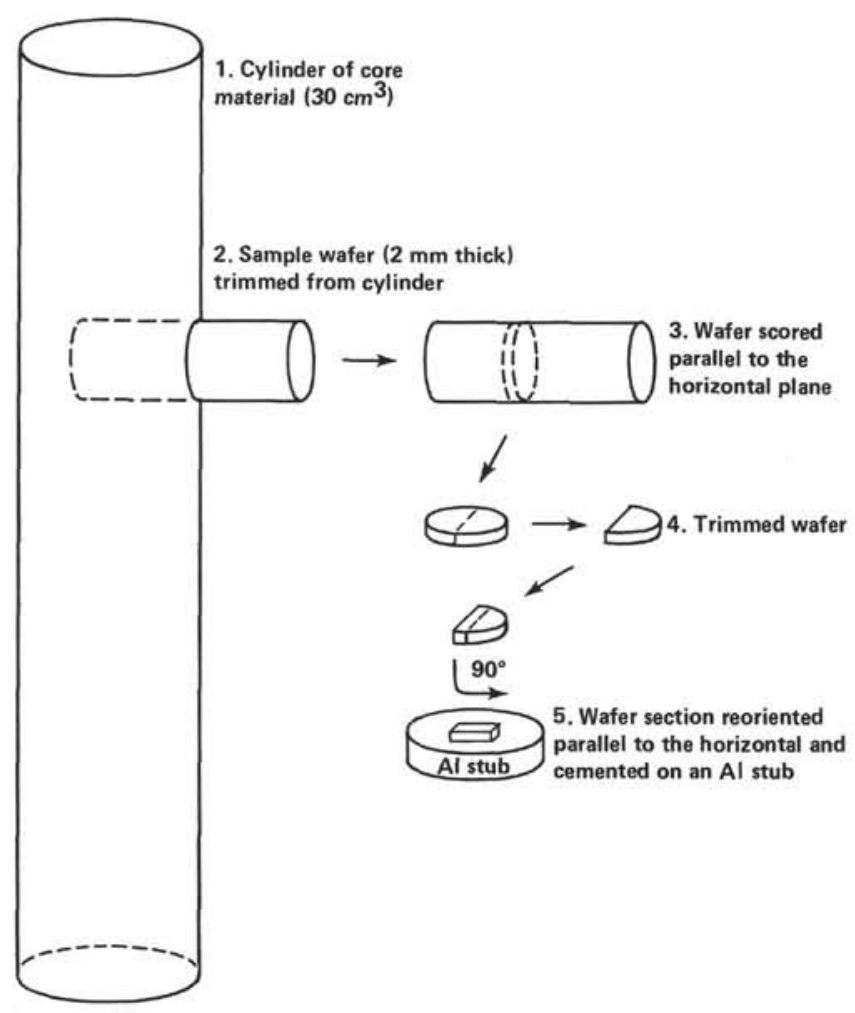

Figure 2. Sample procedure for clay fabric development analysis, Hole $515 \mathrm{~A}$.

occurs as a regular, predictable phenomenon involving closer grain packing, pore-volume reduction, and bulkdensity increase. Hamilton (1976) shows the expectable changes in these parameters for various types of normally compacting marine sediments.

Inasmuch as changes in pore volume, porosity, and density relationships ultimately depend upon overburden pressure, graphs relating overburden pressure to depth in the sediment column will reveal compaction trends. Overburden pressure is calculated from GRAPE (Gamma Ray Attenuation Porosity Evaluater, Evans and Cotterell, 1970) averages/section according to the following (assuming no excess pore pressure):

$$
\bar{\sigma}_{\mathrm{v}}=\left(\varrho_{\mathrm{ws}}-\varrho_{\mathrm{sw}}\right) \mathrm{d},
$$

where

$$
\begin{aligned}
& \bar{\sigma}_{\mathrm{v}}=\text { overburden pressure } \\
& \varrho_{\mathrm{ws}}=\text { wet bulk density of the sediment }\left(\mathrm{Mg} / \mathrm{m}^{3}\right) \\
& \left.\varrho_{\mathrm{sw}}=\text { seawater density (assume } 1.025 \mathrm{Mg} / \mathrm{m}^{3}\right) \\
& \mathrm{d}=\text { depth increment }(\mathrm{m})
\end{aligned}
$$

Hamilton (1976) indicates that no universal curve exists for density and porosity and that each section studied will possess its own unique curve, depending upon a number of complex factors, the most important of which is lithology. Cores from Hole 515A represent a nearly homogeneous lithologic unit, varying between terrigenous mud (T1) and terrigenous sandy mud (T2). Consequently, lithologic variation should be minimal, and the overburden pressure versus depth curve should reveal any deviation from normal compaction by points offset from the general trend. Figure 3 shows the overburden pressure versus depth curve for Hole 515A. The trend is linear down to $32 \mathrm{~m}(150 \mathrm{kPa})$, becoming concave upward with depth. Recalculation of Hamilton's data (1976) shows that this pattern is to be expected in normally compacting homogeneous sediments (Fig. 4). The concave-upward trend begins approximately $10 \mathrm{~m}$ above the "barren" interval, which extends to the base of the core at $108 \mathrm{~m}$. The "barren" zone is attributed to the dissolution of foraminiferal tests with the dissolution "front" beginning at about $32 \mathrm{~m}$. Consequently, the sediment below $32 \mathrm{~m}$ may have changed its character, with closer packing of sediment particles caused by removal of the foraminiferal tests. This closer packing would effectively increase the overburden pressure through the "barren" interval, and the section might exhibit progressive overcompaction with respect to the interval extending from the mudline down to $32 \mathrm{~m}$. That such dissolution is occurring is clear in the sample from $90 \mathrm{~m}$ sub-bottom, shown in Plate 1 . The test outline appears undeformed, yet is completely filled with clay particles that must have entered the test before dissolution. However, some packing of the clay particles probably occurred after solution of the test.

Skempton (1970) has shown that, in the absence of laboratory consolidation analyses, a sediment is normally consolidated (i.e., rate of drainage of interstitial waters equals sedimentation rate-all pressure is hydrostatic) if the ratio of the undrained shear strength versus overburden pressure $\left(\tau_{\mathrm{f}} / \bar{\sigma}_{\mathrm{v}}\right)$ ranges between 0.2 to 0.5 and becomes constant with depth. Systematic measurements of shear strength were made aboard ship during core processing. Both the Wykeham Farrance motorized vane and the hand-held Torvane were used. Measurements from both instruments are highly correlated (Fig. 5). The average of two shear strength measurements per core section was used to construct a $\tau_{\mathrm{f}} / \bar{\sigma}_{\mathrm{v}}$ plot (Fig. 3). As expected, the ratio is large in the upper $10 \mathrm{~m}$ but averages about 0.25 from $10 \mathrm{~m}$ down to $50 \mathrm{~m}$, indicating that the section is normally consolidated. Below $50 \mathrm{~m}$, the ratio decreases slightly, indicating a slight degree of overconsolidation (overcompaction) to $100 \mathrm{~m}$.

A final test of compaction behavior was made by "decompacting" the section (following Hamilton, 1976). In this analysis, each lithology is expanded back to its initial depositional void ratio (void ratio = volume voids/ volume solids). The analysis follows the equation.

$$
\mathrm{H}_{\mathrm{o}}=\mathrm{H}_{\mathrm{p}}\left(1+\mathrm{e}_{\mathrm{o}} / 1+\mathrm{e}_{\mathrm{p}}\right) \text {, }
$$

where

$$
\begin{aligned}
& \mathrm{H}_{\mathrm{o}}=\text { original thickness } \\
& \mathrm{H}_{\mathrm{p}}=\text { present thickness } \\
& \mathrm{e}_{\mathrm{o}}=\text { initial void ratio } \\
& \mathrm{e}_{\mathrm{p}}=\text { present void ratio }
\end{aligned}
$$

Because only two lithologies (T1 and T2) are involved (Fig. 3), an initial, uncompacted void ratio of 2.57 was assumed (Hamilton, 1976). Table 1 shows that the entire section is $27 \%$ compacted and that compaction increases 


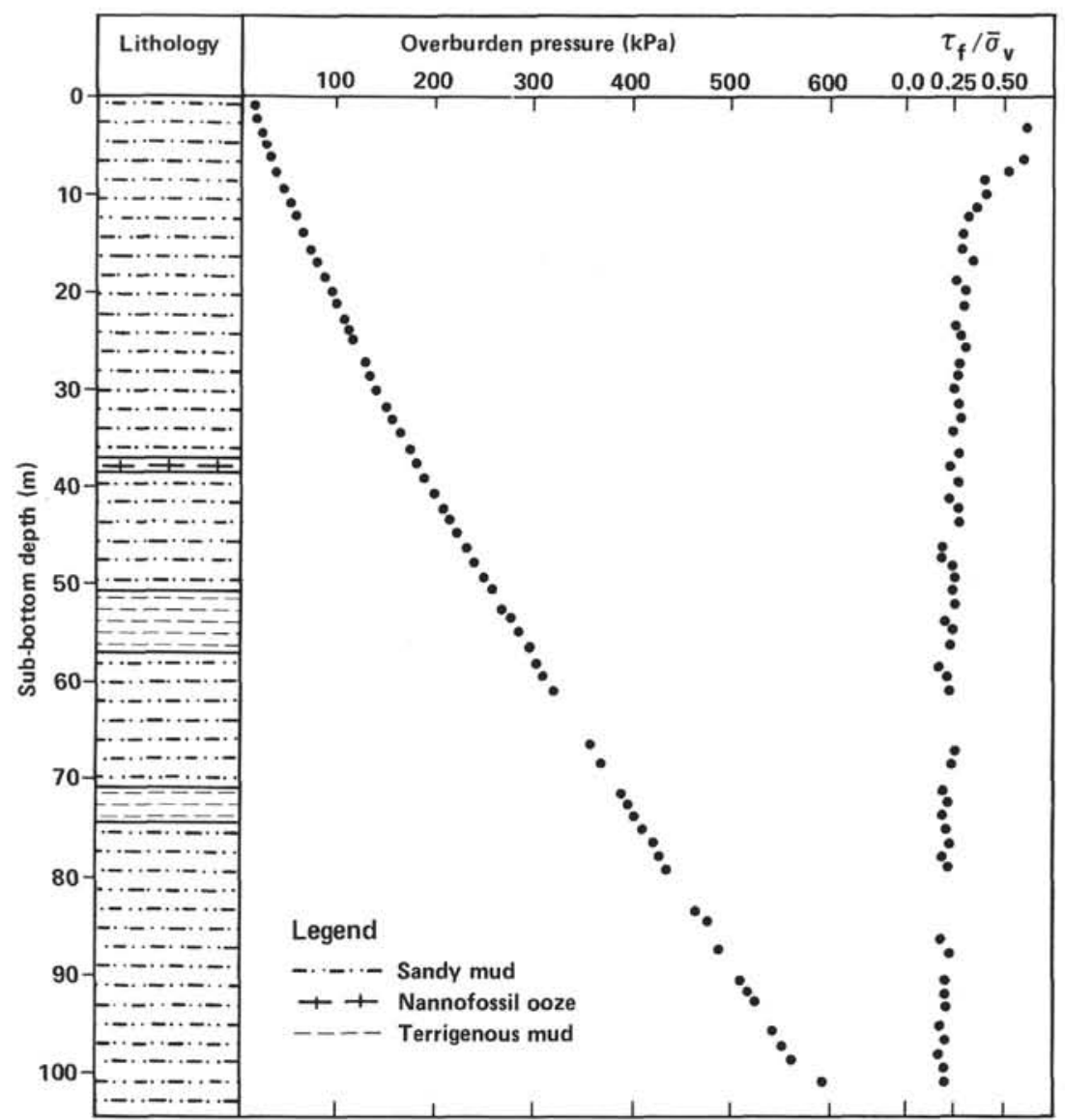

Figure 3. Overburden pressure versus depth curve, Hole 515A. $\tau_{\mathrm{f}}=$ undrained shear strength, $\bar{\sigma}_{\mathrm{v}}=$ overburden pressure.

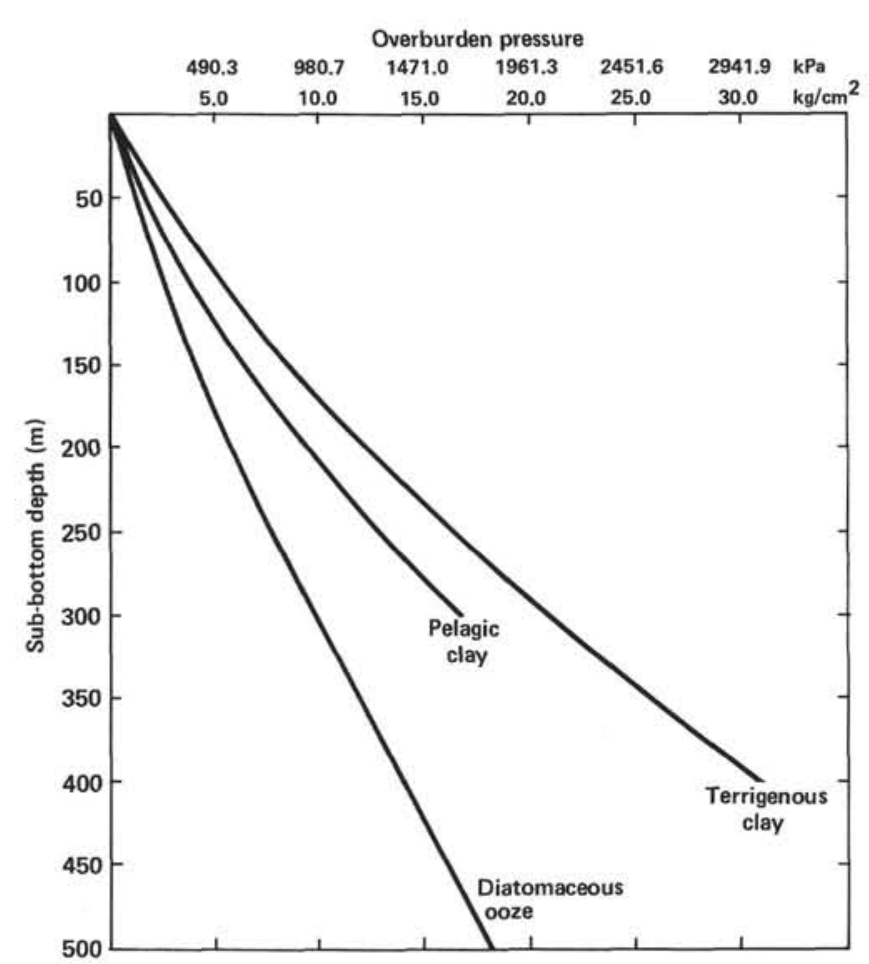

Figure 4. Overburden pressure versus depth curves for commonly occurring marine sediment types (data from Hamilton, 1976). with depth to a maximum of $33 \%$ between 74.5 and 104 $\mathrm{m}$. A decompaction analysis for the normally compacting terrigenous mud (Hamilton, 1976) shows that compaction in excess of $20 \%$ does not occur before $100 \mathrm{~m}$ depth (Table 2). Consequently, because the interval from $38.5 \mathrm{~m}$ to $104 \mathrm{~m}$ in Hole $515 \mathrm{~A}$ exceeds that compaction value, the interval is considered to be somewhat overcompacted, corresponding to the interpretation made from the $\tau_{\mathrm{f}} / \bar{\sigma}_{\mathrm{v}}$ curve.

\section{SEM OBSERVATIONS}

As expected, the sediment fabric exhibited a regular and predictable development as the void ratio was reduced from 2.78 to 1.41 and the overburden pressure increased from $5.0 \mathrm{kPa}$ (Sample 515A-1-1, 105-107 cm) to $590 \mathrm{kPa}$ (Sample 515A-25-2, 145-147 cm). The changes were most striking between the overburden pressure interval from 5 to $200 \mathrm{kPa}$ (mudline to $41 \mathrm{~m}$ ). In this interval, particle orientation changed from single, paralleloriented domains with open void spaces (Plate 2) to edge-to-face large and small aggregates and domains forming an interlocking triangular high void space network (Plate 3). Collapse of the linkages between domains occurred at overburden pressures greater than 50 $\mathrm{kPa}$. Domains became compressed into planar-oriented structural units with FF contacts that still exhibited significant void space between adjacent domains (Plate 4, $150 \mathrm{kPa}$ overburden pressure). 


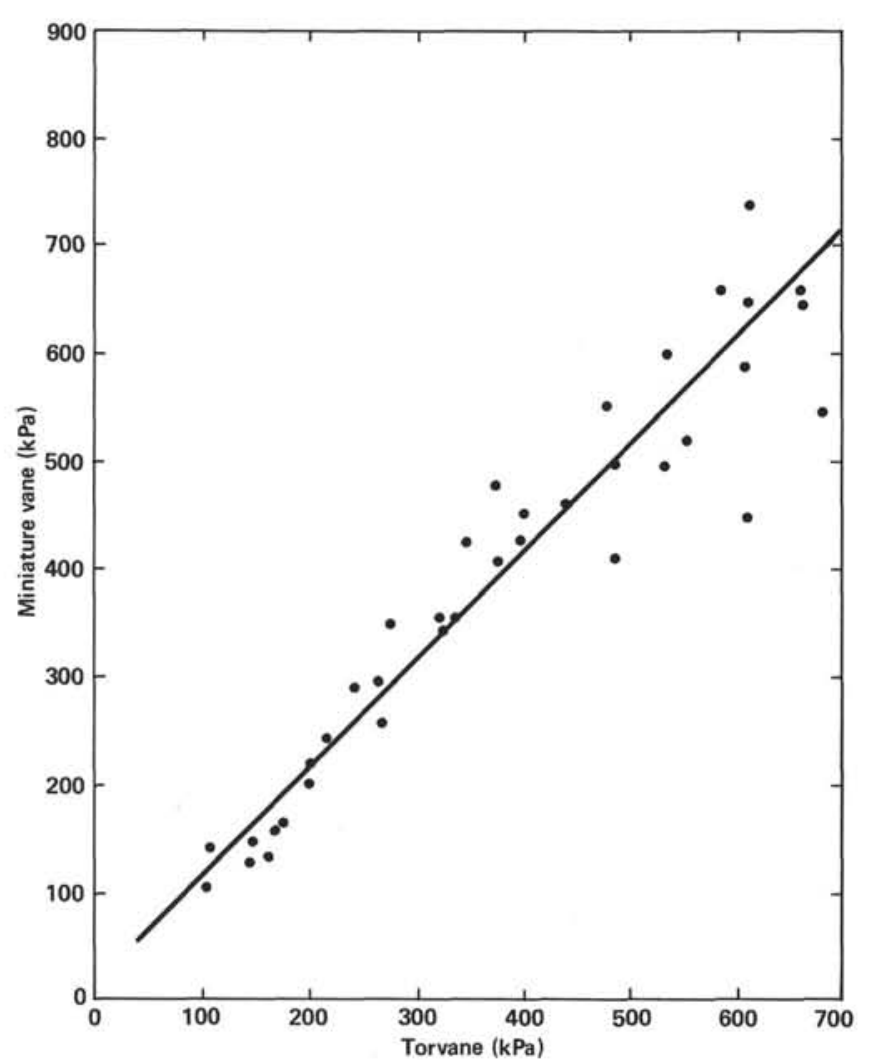

Figure 5. Correlation between Torvane and miniature vane shear strengths, Hole 515A. $\mathrm{y}=0.9963 \mathrm{X}+15.7391 ; \mathrm{r}=0.98$.

Table 1. Decompaction analysis for Hole 515A.

\begin{tabular}{cccrl}
\hline $\begin{array}{c}\mathrm{H}_{\mathrm{p}} \\
(\mathrm{m})\end{array}$ & $\mathrm{e}_{\mathrm{p}}$ & $\mathrm{e}_{\mathrm{o}}$ & $\begin{array}{c}\mathrm{H}_{\mathrm{o}} \\
(\mathrm{m})\end{array}$ & $\begin{array}{c}\% \text { compactions } \\
\text { per interval }\end{array}$ \\
\hline $0-37.5$ & 1.83 & 2.57 & 47.3 & $21 \%$ \\
$37.5-38.5$ & 1.88 & 2.51 & 1.2 & $17 \%$ \\
$38.5-51$ & 1.66 & 2.57 & 16.78 & $26 \%$ \\
$51-57$ & 1.65 & 2.87 & 8.08 & $26 \%$ \\
$57-71$ & 1.60 & 2.57 & 19.22 & $27 \%$ \\
$71-74.5$ & 1.55 & 2.57 & 4.90 & $29 \%$ \\
$74.5-104$ & 1.39 & 2.57 & 44.06 & $33 \%$ \\
& & & 141.54 & $\begin{array}{c}\text { Section is } 27 \% \\
\text { compacted }\end{array}$ \\
\hline
\end{tabular}

Note: $\mathrm{H}_{\mathrm{p}}=$ present thickness of sediment; $\mathrm{e}_{\mathrm{p}}=$ present void ratio; $\mathrm{e}_{\mathrm{O}}=$ initial void ratio; $\mathrm{H}_{\mathrm{O}}=$ original uncompacted sediment $=\mathrm{H}_{\mathrm{p}}\left(1+\mathrm{e}_{\mathrm{o}} / 1+\mathrm{ep}_{\mathrm{p}}\right)$. From Hamilton's data (1976): for terrigenous clay (T1 and T2), $\mathrm{e}_{\mathrm{O}}=2.57$; for nannofossil ooze (CB3), $\mathrm{e}_{\mathrm{O}}=2.53$.

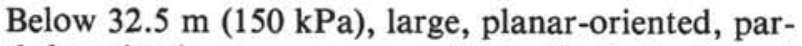
allel domains become common (Plate 5). Reduction of void space between domains by small particle infilling and short linkages is shown in Plate $6(200 \mathrm{kPa})$, but is best seen in Plate 7, in which single clay particles can be seen in EF configuration with large, well-formed domains.

A distinct change in orientation and packing geometry occurs in Section 515A-14-1, 103-105 cm, at $300 \mathrm{kPa}$ overburden pressure, and continues for the remainder
Table 2. Decompaction values for normally compacting, commonly occurring marine sediments (Hamilton, 1976).

\begin{tabular}{lllll}
\hline $\mathrm{H}_{\mathrm{p}}$ & & & $\begin{array}{l}\mathrm{H}_{\mathrm{O}} \\
(\mathrm{m})\end{array}$ & $\begin{array}{l}\% \text { compaction } \\
\text { per increment }\end{array}$ \\
\hline
\end{tabular}

Deep-sea terrigenous sediment ${ }^{\mathrm{a}}$

$\begin{array}{rrrr}50 & 2.14 & 56.85 & 12.0 \\ 100 & 1.81 & 63.52 & 21.3 \\ 150 & 1.56 & 69.72 & 28.3 \\ 200 & 1.35 & 75.96 & 34.1 \\ 300 & 1.02 & 176.79 & 43.4 \\ 400 & 0.80 & 198.33 & 49.6 \\ 500 & 0.64 & 217.69 & 54.0 \\ & & 858.86 & \end{array}$

Deep-sea diatomaceous ooze $\mathrm{e}^{\mathrm{b}}$

$\begin{array}{rrrr}50 & 5.06 & 51.07 & 2.1 \\ 100 & 4.32 & 58.18 & 14.0 \\ 150 & 3.76 & 65.02 & 23.1 \\ 200 & 3.37 & 70.82 & 29.4 \\ 300 & 2.85 & 160.78 & 37.8 \\ 400 & 2.57 & 173.39 & 42.3 \\ 500 & 2.45 & 179.42 & 44.3 \\ & & 758.68 & \end{array}$

Deep-sea pelagic clayc

$\begin{array}{rrrr}50 & 3.42 & 60.18 & 16.9 \\ 100 & 2.72 & 71.50 & 30.0 \\ 150 & 2.22 & 82.61 & 39.5 \\ 200 & 1.81 & 94.66 & 47.2 \\ 250 & 1.50 & 106.40 & 53.0 \\ 300 & 1.25 & 118.22 & 57.7 \\ & & 533.57 & \end{array}$

Note: See Table 1 for explanation of variables. ${ }^{\mathrm{a}} \mathrm{e}_{\mathrm{O}}=2.57$, total compaction $=41.8 \%$. b $\mathrm{e}_{\mathrm{O}}=6.19$, total compaction $=34.0 \%$. c $\mathrm{e}_{\mathrm{O}}=4.32$, total compaction $=43.8 \%$.

of the core. Large and small domains have coalesced in an FF configuration to form large platelike masses (Plate 8; Plate 9, Fig. 1). Voids exist mainly between adjacent masses and often have small isolated domains infilling them in various orientations (Plate 9, Fig. 2). Void ratio has decreased from 2.70 to 1.63 , a reduction of $41.4 \%$ in void volume.

Domain formation and void space reduction by small particle infilling continues between 300 to $400 \mathrm{kPa}$ overburden pressure. Plate 10, Figure 1, shows a compact unit of largely FF-oriented platy aggregates with crenulated margins. This "cornflake" structure appears to be typical of highly crystalline montmorillonite (Scholle, 1979). Planar packing of large domains results in lower void space (Plate 10, Fig. 2).

At $485 \mathrm{kPa}$ overburden pressure, an amorphous "glazing"' appears (Plate 11). This "glazing"' appears to extend through the base of the core and further reduces void volume, in addition to coating particles and domains.

The first clear indication of orientation perpendicular to the core axis (i.e,. bedding plane orientation) is in Sample 515A-23-1, 142-144 cm (Plate 12, Figure 1). The solid material consists of large "booklike" domains com- 
posed of stepwise FF-oriented platelets, some of which are deformed. A massive unit of coalesced and oriented domains is seen in Plate 12, Figure 2. All appear to be generally FF-oriented parallel to bedding. Void spaces occur only between the coalesced domains as discrete, unfilled cavities.

Sample 515A-24-2, 40-42 cm (Plate 13) shows textural anisotropy; discrete linear and curvilinear areas occur parallel to bedding as "veins" surrounded by a generally homogeneous matrix. A closer observation of these "veins"' (Plate 13, Fig. 2) shows that they consist of overlapping, highly oriented FF plates, surrounded by individual, less well-oriented plates. Void space is nonexistent within the "veins" and occurs only as discrete spaces in the less well-oriented matrix. Plate 13, Figure 3, clearly reveals that the "veins" are composed of overlapping, FF-oriented small domains and are curved over each other. Void ratio is 1.50 and overburden pressure is $550 \mathrm{kPa}$.

In Plate 14, the fabric from Sample 515A-25-2, 116 $118 \mathrm{~cm}$, at $590 \mathrm{kPa}$ overburden pressure is shown. The fabric consists of well-crystallized montmorillonite plates, generally in an FF configuration. Distortion of the plates leads to conical voids within the overall matrix (Plate 14, Fig. 1). Parallel, planar orientation of overlapping plates in FF configuration, occasionally interrupted by small plates oriented perpendicular to the larger masses, is seen in Plate 14, Figure 2. Particle packing has reduced the void ratio to 1.41 and increased bulk density to $1.725 \mathrm{Mg} / \mathrm{m}^{3}$.

\section{DISCUSSION}

Clay fabric development in Hole 515A appears to follow the pattern suggested by Bennett and others (1979). In the upper $30 \mathrm{~m}$, void ratios greater than 2.00 (high porosity) are associated with a fabric consisting of randomly oriented domains, often linked by smaller domains in an EF configuration. Large voids, usually equidimensional, occur between domains and their linkages, and the result is a highly compressible, water-rich sediment.

As overburden pressure increases, the previously randomly oriented domains are forced into a more parallel, $\mathrm{FF}$ arrangement. Bridging between domains still occurs in Sample 515A-10-1, 49-51 cm (Plate 6) (200 kPa overburden pressure), but nearly complete parallel alignment of domains occurs in Sample 515A-14-1, 103-105 cm (Plate 8$)(300 \mathrm{kPa}$ overburden pressure). The slope of the graph of overburden pressure with depth (Fig. 3), moreover, changes significantly at Core 16 of Hole 515A $(40 \mathrm{~m})$, which may have resulted from closer particle packing (see discussion of overcompaction effects in "Data Analysis" section).

Although particle rearrangement within the sediment from Hole $515 \mathrm{~A}$ was expected and is demonstrated in the upper $40 \mathrm{~m}$ (overburden pressure to $200 \mathrm{kPa}$ ), the development of thin, coalesced units of clay particles (Plate 8; Plate 9, Fig. 1) was unanticipated. The process remains unclear. The existence of well-crystallized smectite and kaolinite (?) (Plate 9, Fig. 1; Plate 10, Fig. 1) under low overburden pressures $(400 \mathrm{kPa})$ also poses a problem to early diagenesis. The "glazing" that coats the domains and individual clay particles from Cores 21 to 25 in Hole 515A (Plate 11) is also a contributor to early lithification.

Clay particles appear to be subject to mechanical reorientation under overburden pressures up to $200 \mathrm{kPa}$. At greater pressures, compression of existing structures with resulting void ratio reduction occurs. Coalescing of particle clusters into oriented domains occurs between 200 to $300 \mathrm{kPa}$. At pressures that are greater than 300 $\mathrm{kPa}$, diagenesis results in highly crystalline clays (smectites, kaolinite).

\section{CONCLUSIONS}

An SEM study of clay fabric development in an undisturbed core $(100 \mathrm{~m})$ from the Vema Channel indicates that preferred orientation of clay particles occurs at overburden pressures of $250 \mathrm{kPa}$ as porosity is reduced from 74 to $61.0 \%$. Meade's (1969) contention that most preferred orientation in clay sediments is developed at pressures of only a few $\mathrm{kg} / \mathrm{cm}^{2}$ seems to apply in this situation. The obvious process seems to involve the coalescing of small packets of FF-oriented particles (small domains) to make up large composite domains. Random orientation changes to preferred orientation at $250 \mathrm{kPa}$ overburden pressure as a result of linkage destruction and incorporation of the linking material into the larger domains, surrounded by a smaller-particle, homogeneous matrix.

The mass properties of the core (its water content, bulk density, and shear strength) may change in a regular and predictable fashion, following a regular increase in packing of particles (Table 3). At overburden pressures greater than $590 \mathrm{kPa}$, however, no obvious orientation or mechanical rearrangement of particles is occurring.

Perhaps the most significant process influencing fabric development is the dissolution of carbonates below $32 \mathrm{~m}$ depth in the core. At this level, overburden pres-

Table 3. Physical properties of samples studied from Hole 515A.

\begin{tabular}{|c|c|c|c|c|c|c|c|c|}
\hline $\begin{array}{c}\text { Sample } \\
\text { no. }\end{array}$ & $\begin{array}{l}\text { Sub-bottom } \\
\text { depth }(m)\end{array}$ & $\begin{array}{c}\text { Core-section } \\
\text { (interval in } \mathrm{cm} \text { ) }\end{array}$ & $\begin{array}{c}\text { W } \\
\text { (\% dry } \\
\text { weight) }\end{array}$ & $e\left(\mathrm{Mg} / \mathrm{m}^{3}\right)$ & $(\%)$ & $\begin{array}{c}\mathrm{e} \\
(\%)\end{array}$ & $\stackrel{+}{r}$ & $\begin{array}{c}\bar{\sigma}_{\mathrm{y}} \\
(\mathrm{kPa})\end{array}$ \\
\hline I & 1.06 & $1-1,105-107$ & 51.95 & 1.430 & 74.0 & 2.85 & - & 10 \\
\hline 2 & 6.0 & $2-2,31-33$ & 51.2 & 1.470 & 73.6 & 2.78 & $\begin{array}{l}129.6 \\
156.2 \mathrm{TV}\end{array}$ & 25 \\
\hline 3 & 10.8 & $3-2,42-44$ & 54.16 & 1.430 & 73.5 & 2.77 & $\begin{array}{l}157.4 \\
166.0 \mathrm{TV}\end{array}$ & so \\
\hline 4 & 21.6 & $5-3,83-85$ & 48.68 & 1.504 & 71.5 & 2.51 & $\begin{array}{l}291.7 \\
263.7\end{array}$ & 100 \\
\hline 5 & 32.2 & $8-1,115-117$ & 44.35 & 1.565 & 68.0 & 2.12 & $\begin{array}{l}423.0 \\
346.7 \mathrm{TV}\end{array}$ & 150 \\
\hline 6 & 41.2 & $10-1,49-51$ & 42.56 & 1.593 & 64.5 & 1.82 & $\begin{array}{l}464.4 \\
415.0 \mathrm{TV}\end{array}$ & 200 \\
\hline 7 & 49.5 & $12-1,134-136$ & 39.28 & 1.644 & 63.0 & 1.70 & $\begin{array}{l}642.4 \\
610.3 \mathrm{TV}\end{array}$ & 250 \\
\hline 8 & 59.6 & $14-1,103-105$ & 37.18 & 1.680 & 62.0 & 1.63 & $\begin{array}{l}443.8 \\
610.3 \mathrm{TV}\end{array}$ & 300 \\
\hline 9 & 65.0 & $16-1,83-85$ & 36.78 & 1.686 & 61.5 & 1.60 & $\begin{array}{l}911.0 \\
854.4 \mathrm{TV}\end{array}$ & 350 \\
\hline 10 & 73.5 & $17-3,17-19$ & 37.01 & 1.683 & 61.5 & 1.60 & $732.4 \mathrm{TV}$ & 400 \\
\hline 11 & 85.5 & $21-1,39-41$ & 38.25 & 1.662 & 61.0 & 1.56 & $\begin{array}{l}852.6 \\
976.5 \mathrm{TV}\end{array}$ & 485 \\
\hline 12 & 90.0 & $23-1,142-144$ & 37.87 & 1.668 & 61.0 & 1.56 & $\begin{array}{l}957.8 \\
988.7 \mathrm{TV}\end{array}$ & 510 \\
\hline 13 & 96.5 & $24-2,40-42$ & 35.15 & 1.715 & 60.0 & 1.50 & $\begin{array}{l}992.8 \\
952.1\end{array}$ & 550 \\
\hline 14 & 100.2 & $25-2,116-118$ & 34.60 & 1.725 & 58.5 & 1.41 & $\begin{array}{l}1320.0 \\
1221.0 \mathrm{TV}\end{array}$ & 590 \\
\hline 15 & 100.5 & $25-2,145-147$ & 34.60 & 1.725 & 58.5 & 1.41 & - & 590 \\
\hline
\end{tabular}

Note: $W=$ water content; $\rho=$ density; $\eta=$ porosity; $e=$ void ratio; $\tau=$ shear strength; $\bar{\sigma}_{\mathrm{V}}=$ over burden pressure; $\mathrm{TV}=$ Torvane measurement of shear strength. 
sure increases abruptly, void ratio decreases, and the $\tau_{\mathrm{f}} /$ $\bar{\sigma}_{\mathrm{v}}$ ratio decreases below 0.25 , implying a slightly overcompacted sediment.

Our analysis indicates that preferred orientation of clay particles may develop in an undisturbed, normally consolidated sediment at overburden pressures approximately those suggested by Bowles and others (1969) from laboratory consolidation studies. Our results also substantiate the fabric development model described by Bennett and others (1981) in which clays with high void ratios are reduced by overburden pressure to clays with low void ratios.

\section{REFERENCES}

Bennett, R. H., Bryant, W. R., and Keller, G. H., 1979. Clay fabric and related pore geometry of selected submarine sediments: Mississippi Delta. Scanning Electron Microsc., 1:519-524.

1981. Clay fabric of selected submarine sediments: fundamental properties and models. J. Sediment. Petrol., 51(1):217-231.

Bohlke, B. M., and Bennett, R. H., 1980. Mississippi prodelta crusts: a clay fabric and geotechnical analysis. Mar. Geotechnol., 4(1): 55-81.

Bowles, F. A., Bryant, W. R., and Wallin, C., 1969. Microstructure of unconsolidated and consolidated marine sediments. J. Sediment. Petrol., 39:1546-1551.

Brewer, R., and Haldane, A. D., 1957. Preliminary experiments in the development of clay orientation in soils. Soil Sci., 84:301-309.
Bryant, W. R., Delflache, A. P., and Trabant, P. K., 1974. Consolidation of marine clays and carbonates. In Inderbitzen, A. L. (Ed.), Deep Sea Sediments: Physical and Mechanical Properties: New York (Plenum Press), pp. 209-244.

Evans, H. B., and Cotterell, C. H., 1970. Gamma ray attenuation density scanner. In Peterson, M. N. A., Edgar, N. T., et al., Init. Repts. DSDP, 2: Washington (U.S. Govt. Printing Office), 460-462.

Hamilton, E. L., 1976. Variations of density and porosity with depth in deep sea sediments. J. Sediment. Petrol., 46(2):280-300.

Hedberg, H. D., 1936. Gravitational compaction of clays and shales. Am. J. Sci., 31:241-287.

Meade, R. H., 1966. Factors influencing the early stages of compaction of clays and sands: review. J. Sediment. Petrol., 36(4): 1085-1101.

Rosenquist, I. Th., 1959. Physico-chemical properties of soils: soilwater systems. J. Soil Mech. Found. Div. Am. Soc. Civ. Eng., 85: 31-53.

Scholle, P. A., 1979. Constituents, textures, cements, and porosities of sandstones and associated rocks. Am. Assoc. Pet. Geol. Mem., 28.

Skempton, A. W., 1970. The consolidation of clays by gravitational compaction. Q. J. Geol. Soc. London, 125:373-411.

Weller, J. M., 1959. Compaction of sediments. Am. Assoc. Pet. Geol. Bull., 43:273-310.

Date of Initial Receipt: March 23, 1982 


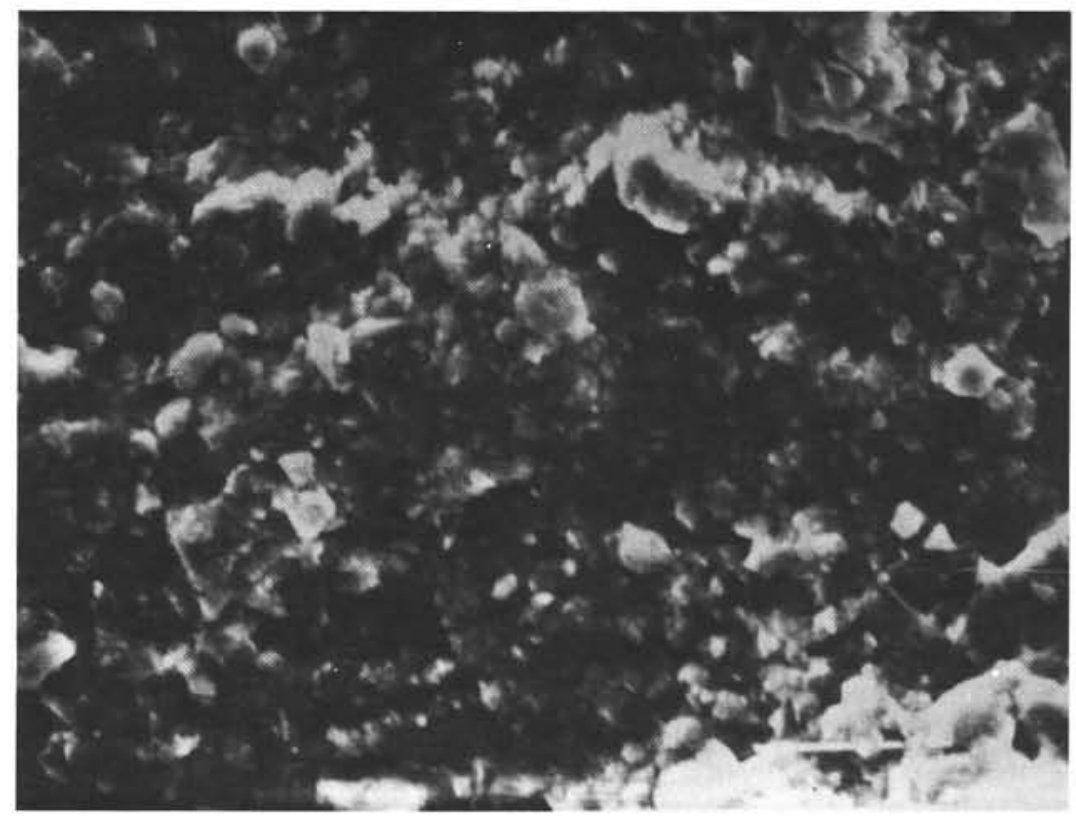

Plate 1. Sample 515A-23-1, 142-144 cm; outline of dissolved foraminifers completely infilled with clay particles, resulting in closer packing, $\times 1,000$.

In this and the following plates, $\mathrm{EE}=$ edge to edge, $\mathrm{EF}=$ edge to face, and $\mathrm{FF}=$ face to face. Table 3 contains the physical properties data for the samples shown in the plates. All magnifications are original magnifications.

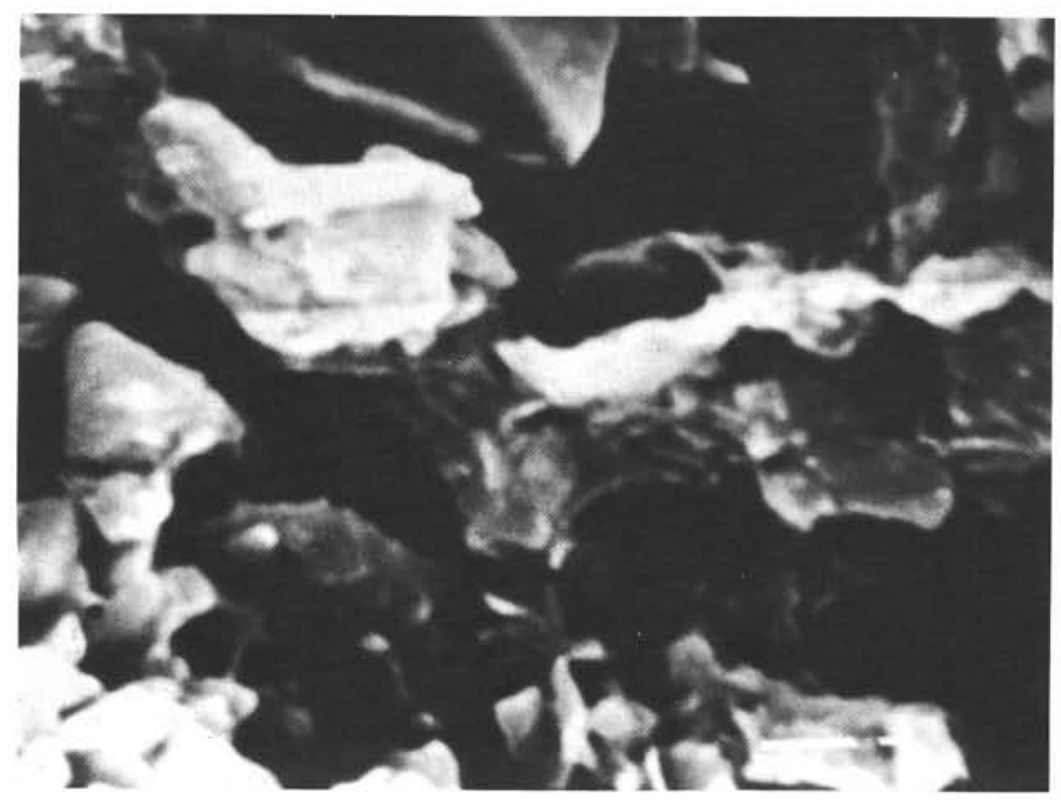

Plate 2. Sample 515A-1-1, 105-107 cm; dominated by single particle, mainly in EE configuration, significant void space; $\times 10,000$. 


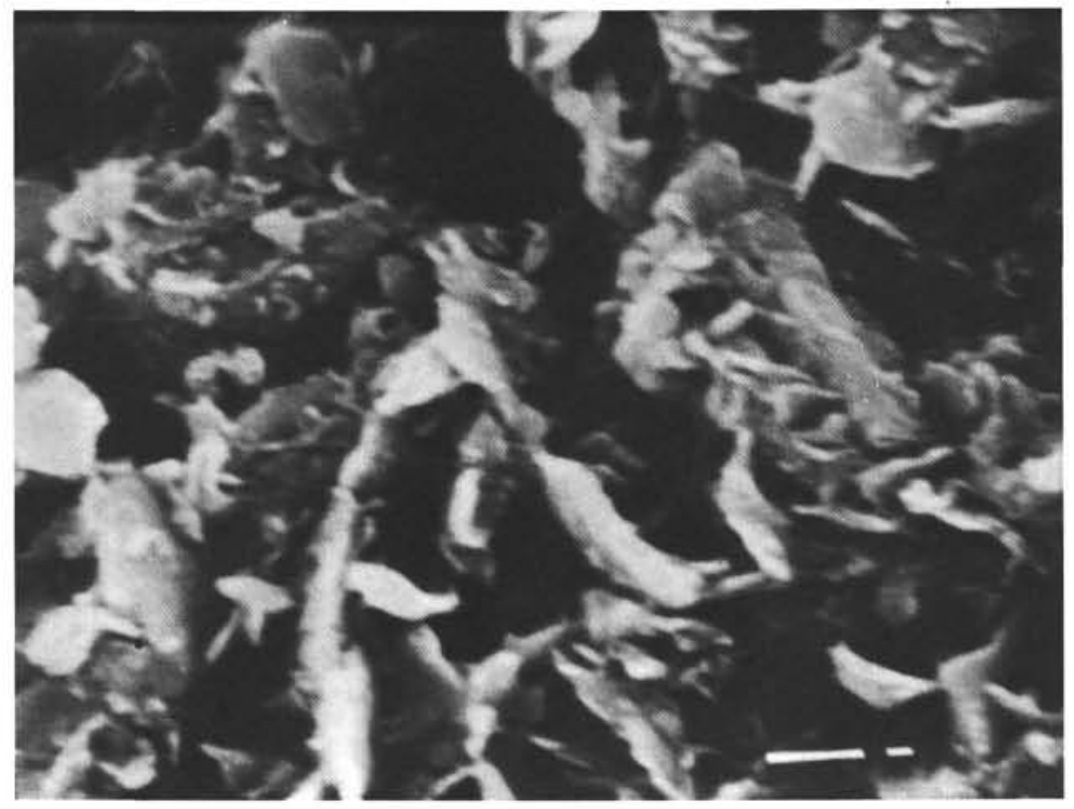

Plate 3. Sample 515A-3-2, 42-44 cm; development of linkages, EE-forming and EFforming boxwork structures, high void ratio, structural units composed of numerous primary particles, a few large domains; $\times 10,000$.

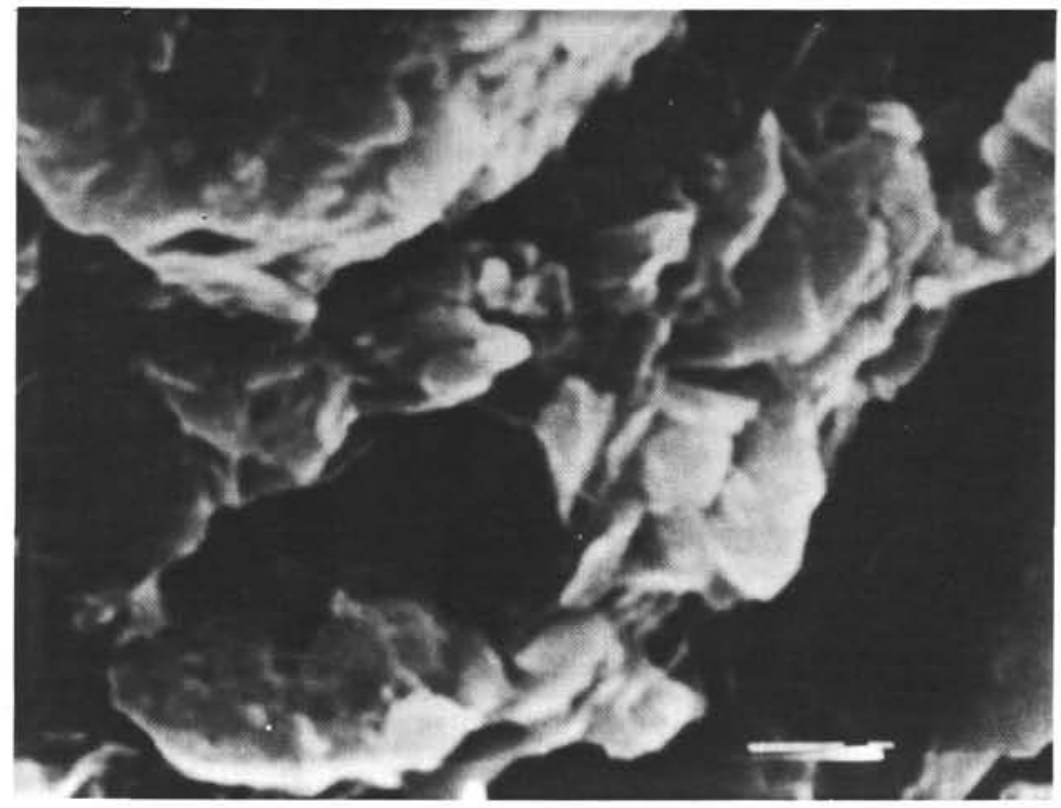

Plate 4. Sample 515A-5-3, 83-85 cm; layering developing FF configuration with booklike domains, high void ratio, collapse of structural FF units; $\times 10,000$. 


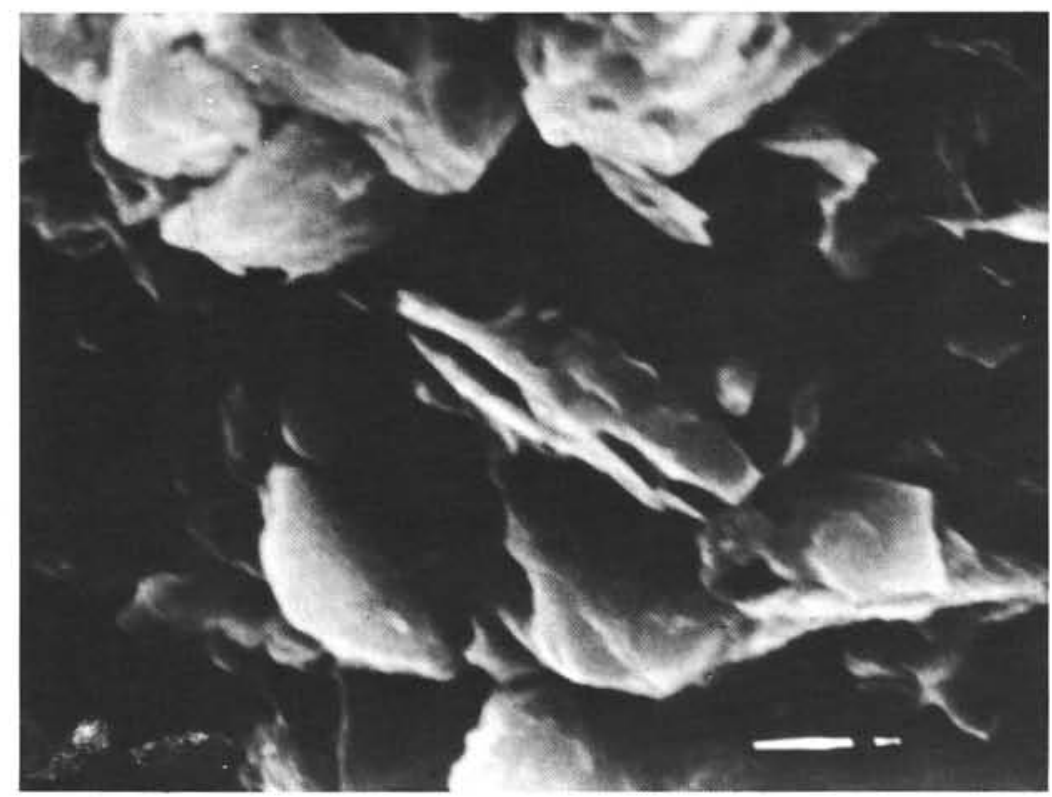

Plate 5. Sample 515A-8-1, 115-117 cm; FF configuration of collapsed EF-linked structural units, large plates likely to be kaolinite; $\times 10,000$.

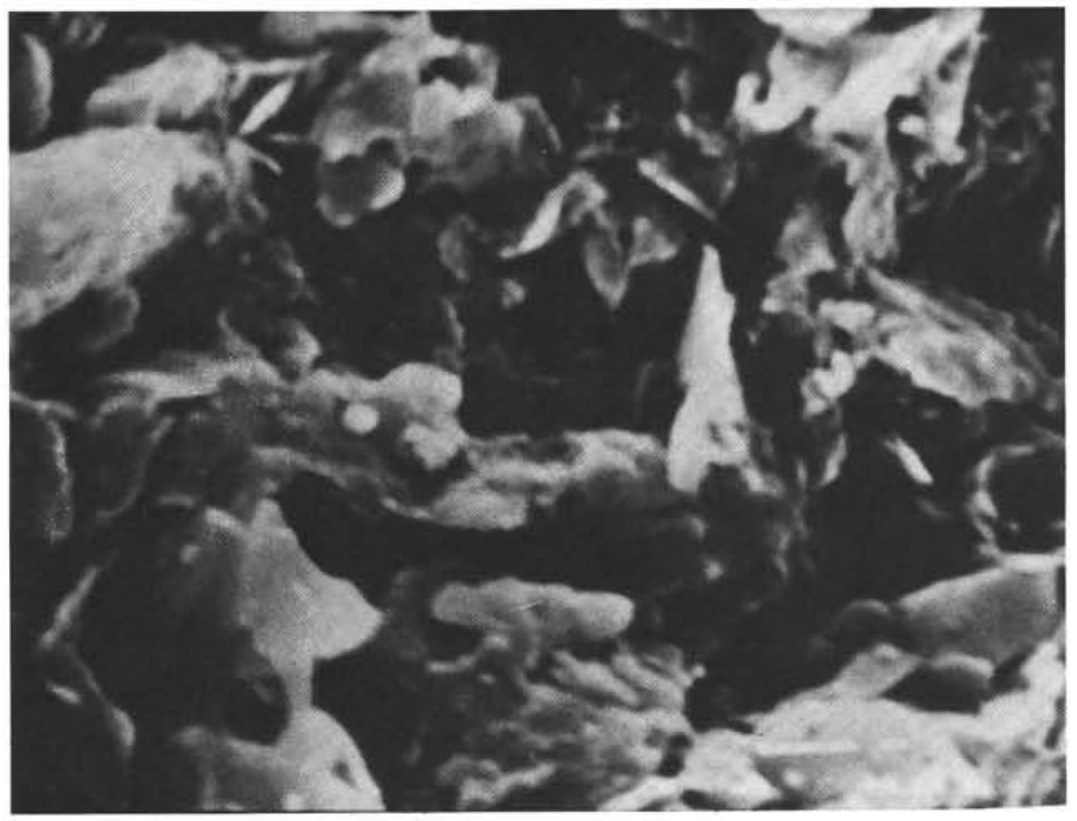

Plate 6. Sample 515A-10-1, 49-51 cm; domain formation, large domains of FF particles linked to each other by smaller domains or single particles in EF configuration, void space is being reduced by smaller particle infilling, with clusters of EE-linked particles; $\times 10,000$. 


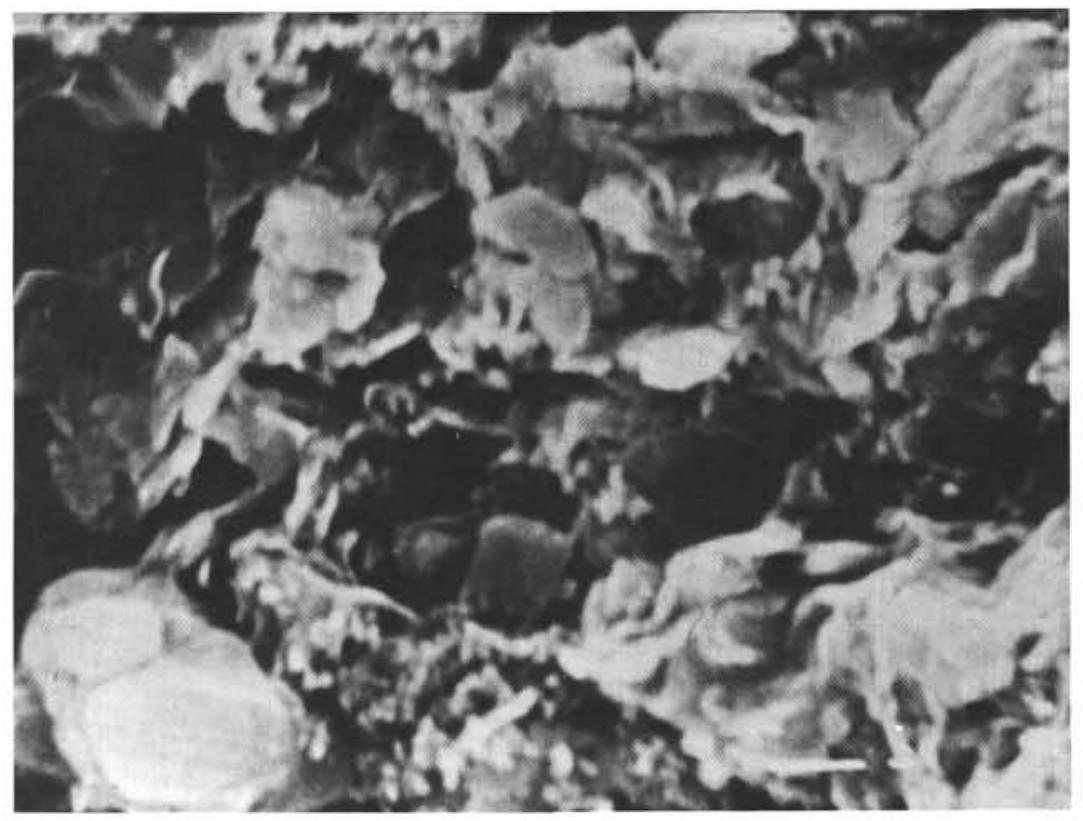

Plate 7. Sample 515A-12-1, 134-136 cm; formation of coherent fabric with significant particle and domain (clusters of FF-oriented particles) becoming planar oriented, domains linked by EF particles in "cardhouse" arrangement, void space reduced, becoming more apparent between domains; $\times 10,000$.

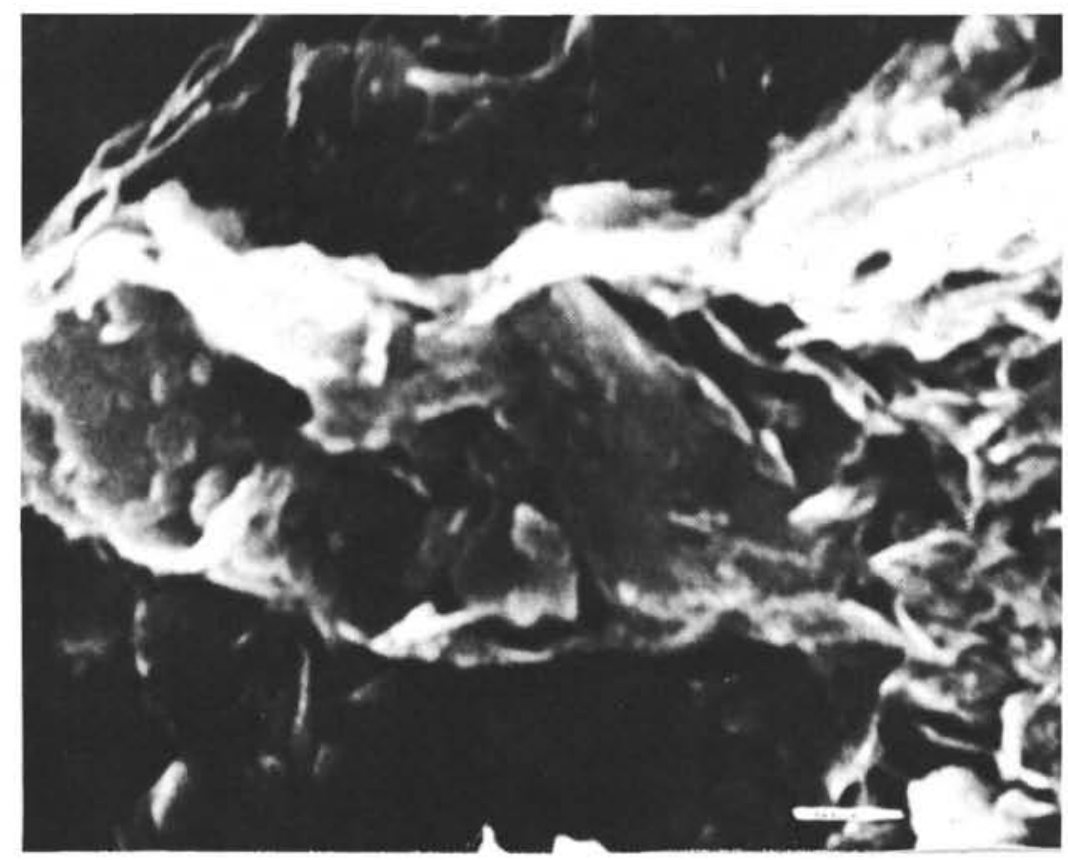

Plate 8. Sample 515A-14-1, 103-105 cm; large masses of coalesced domains, reduction of void space as a result of close packing, area of EF orientation shown in field to right, area of FF orientation shown in field to left; $\times 10,000$. 


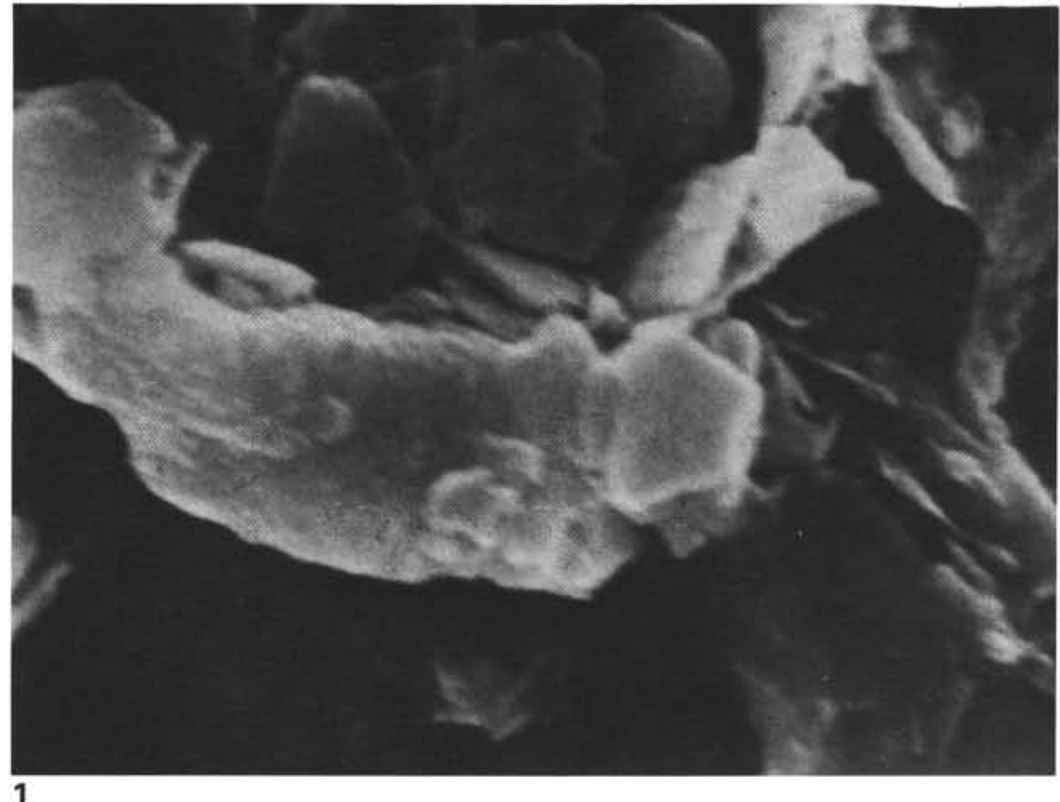

1

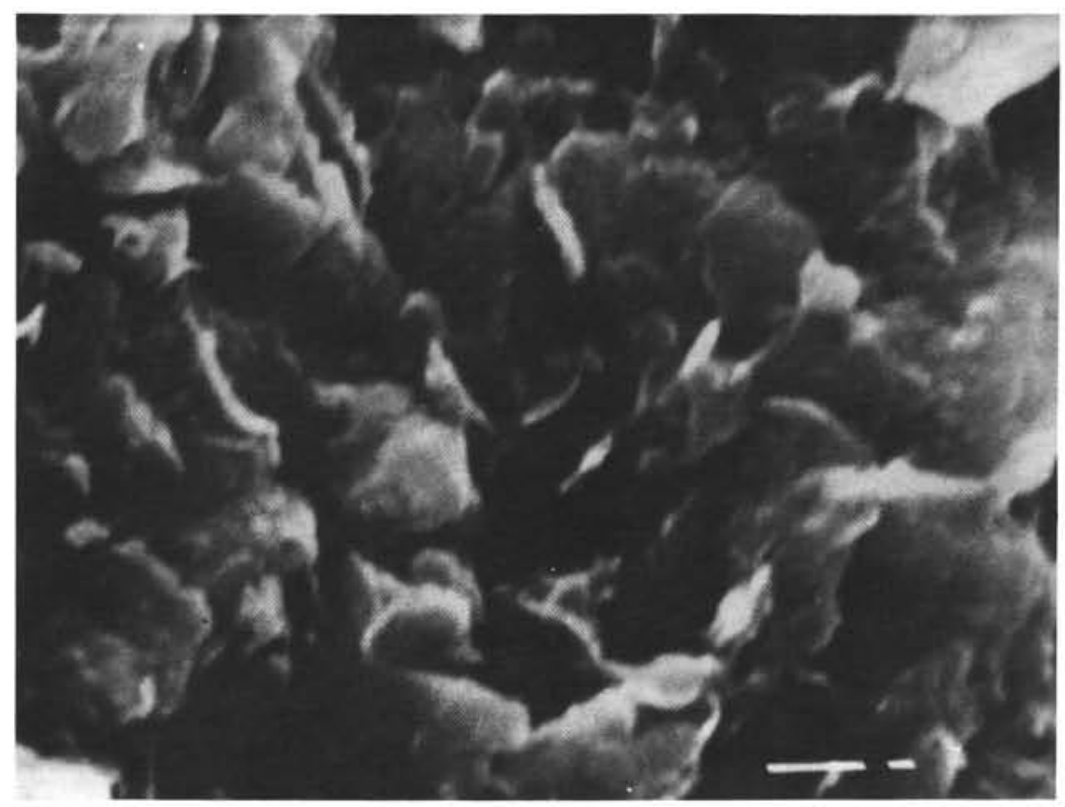

2

Plate 9. Sample 515A-16-1, 83-85 cm, $\times 10,000$. 1. Planar-oriented kaolinite (?) plates, large oriented domains overlapping each other in FF orientation. 2. Planar-oriented plate, nearly all FF-oriented bridges with some EF bridges, void space reduced by close packing. 

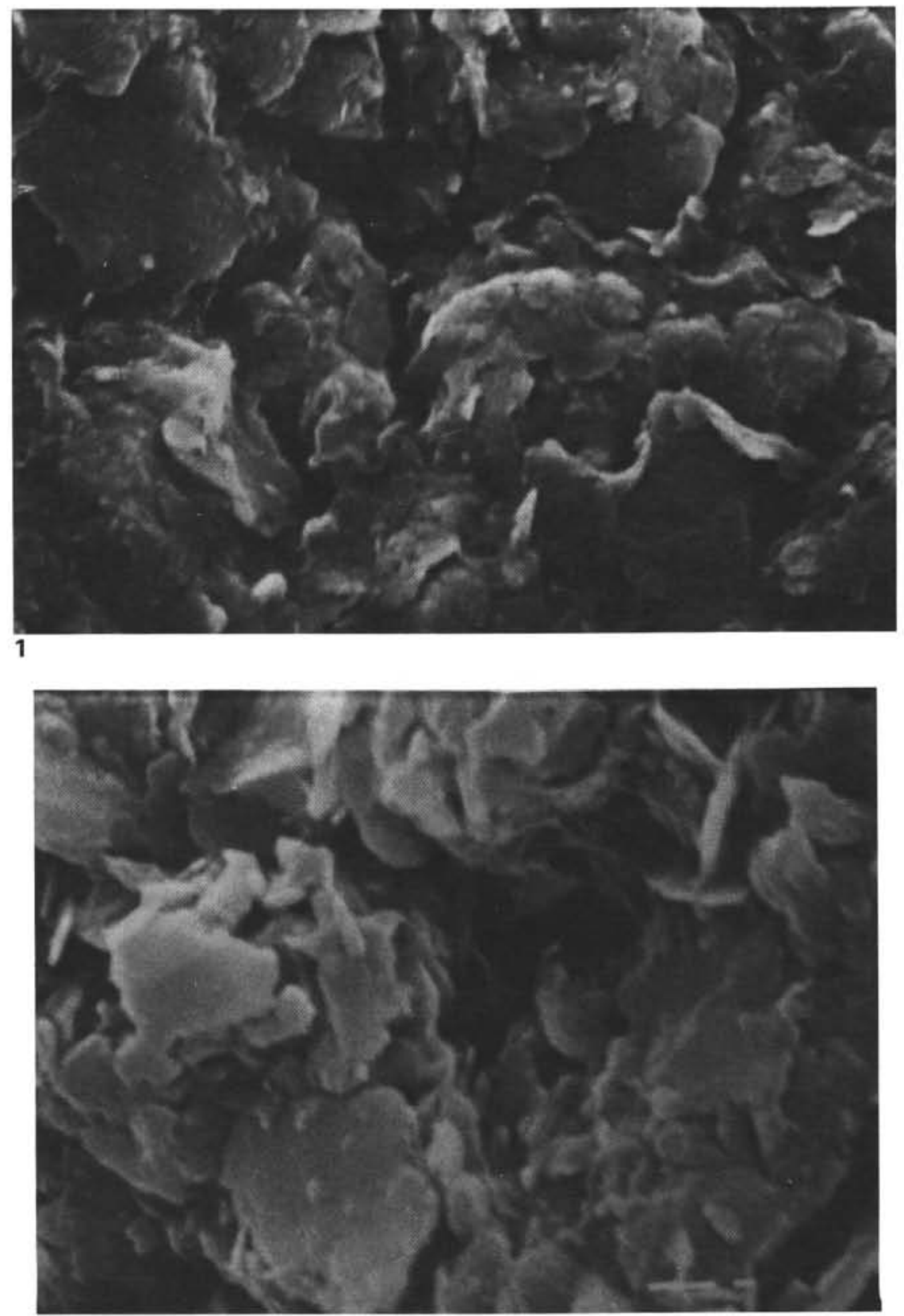

2

Plate 10. Sample 515A-17-3, 17-19 cm, $\times 10,000$. 1. Large and small domains forming a "cornflake" fabric (typical of montmorillonite). 2. FF orientation of large domains, with minor EF-oriented particles, resulting in closer packing and diminished void space. 


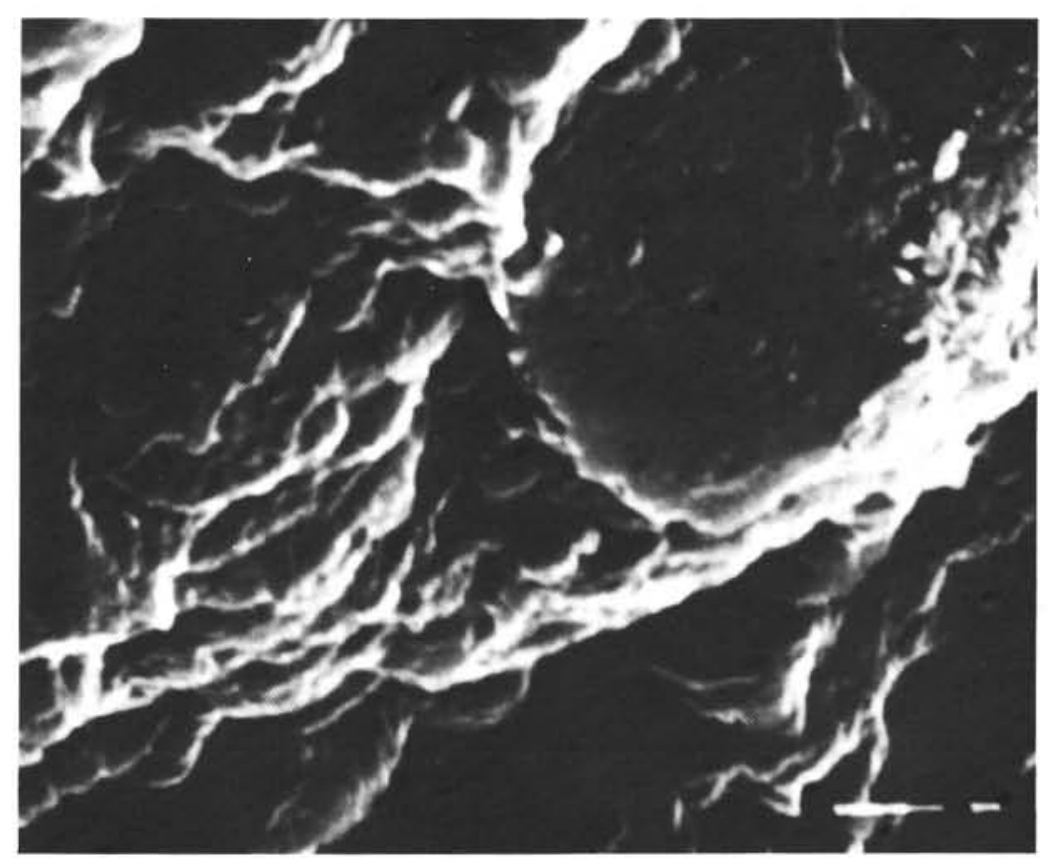

Plate 11. Sample 515A-21-1, 39-41 cm; development of amorphous "glazing" not previously observed; $\times 10,000$. 

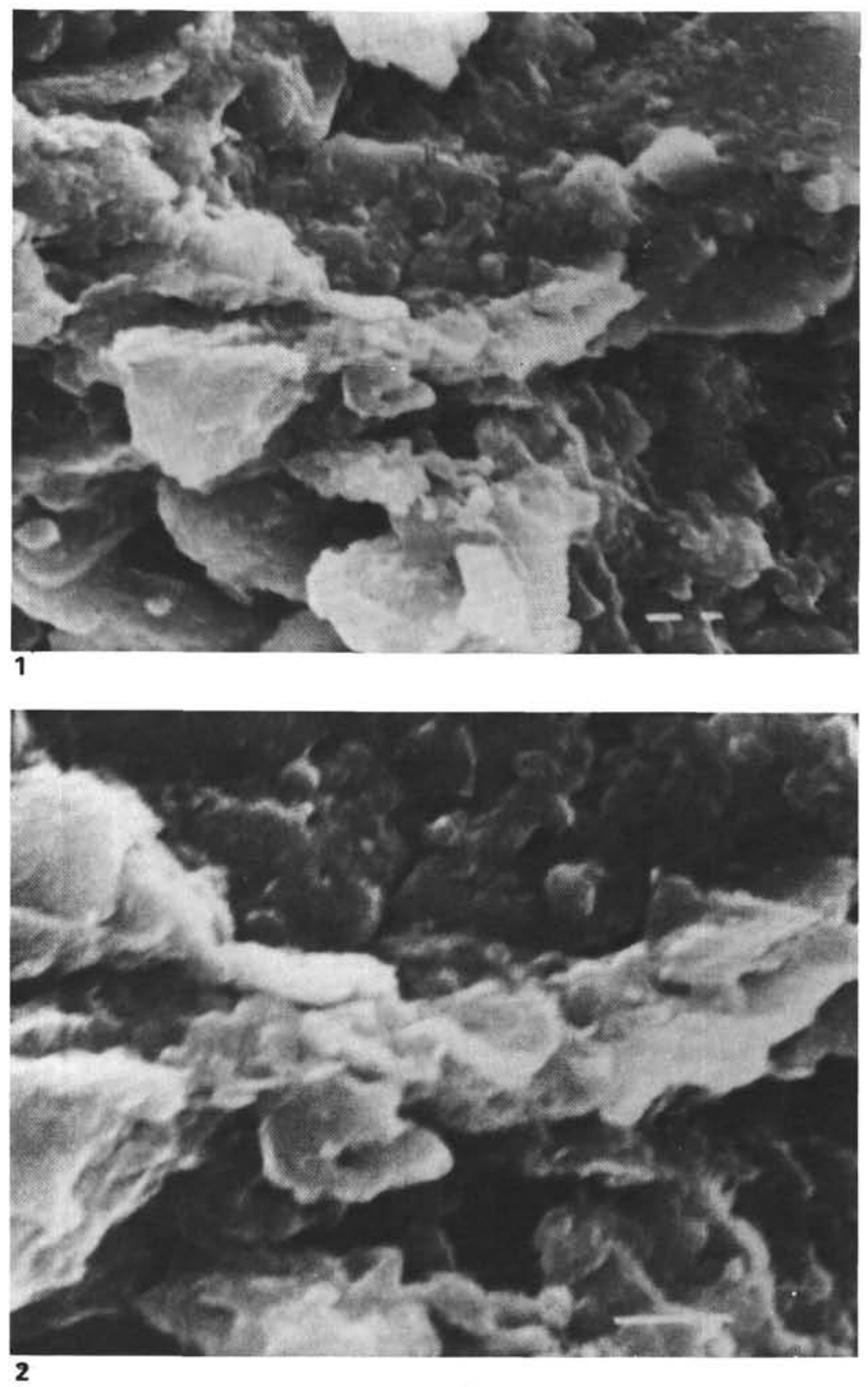

Plate 12. Sample 515A-23-1, 142-144 cm. 1. Domain development parallel to bedding, overburden pressure is $510 \mathrm{kPa}, \times 5000$. 2. FF orientation of small domains and bridged chains in laminae, $\times 10,000$. 


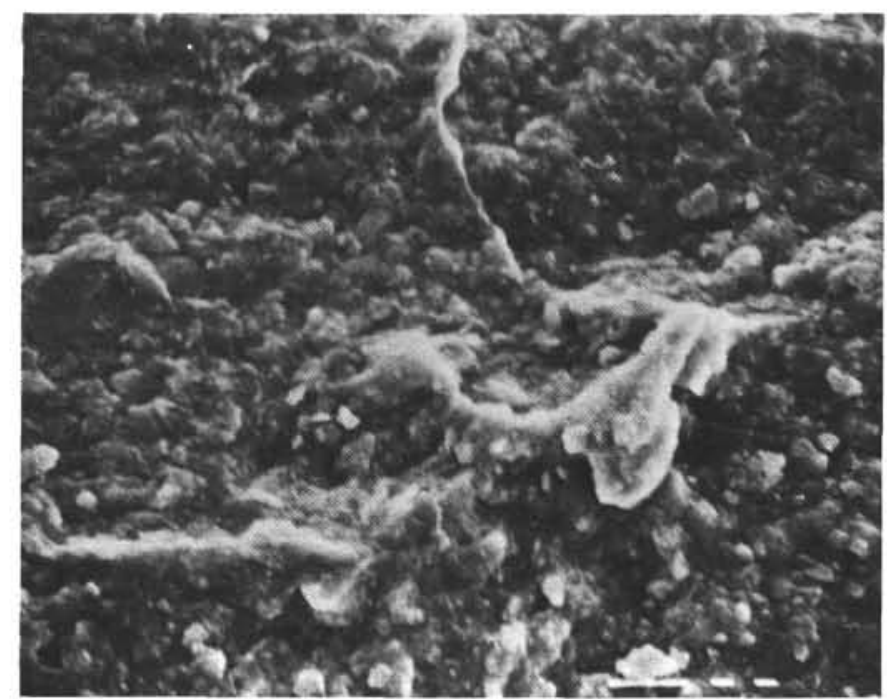

1
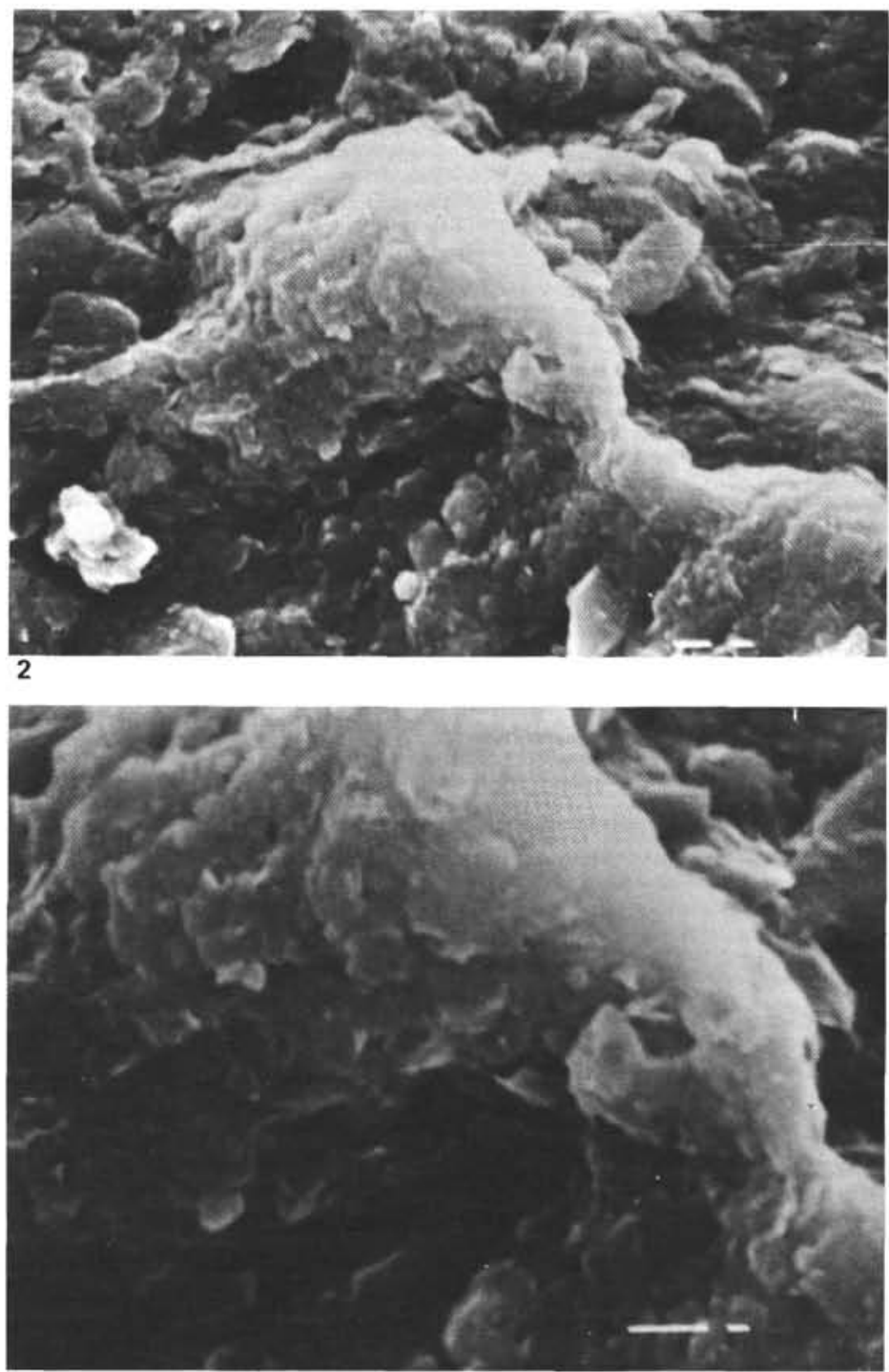

Plate 13. Sample 515A-24-2, 40-42 cm. 1. Linear and curvilinear "veining" surrounded by homogeneous matrix, $\times 1000$. 2. "Vein"' overlapping, FF-oriented small domains, $\times 5000$. 3. "Veins" show stressed overlapping, FF-oriented domains, $\times 10,000$. 


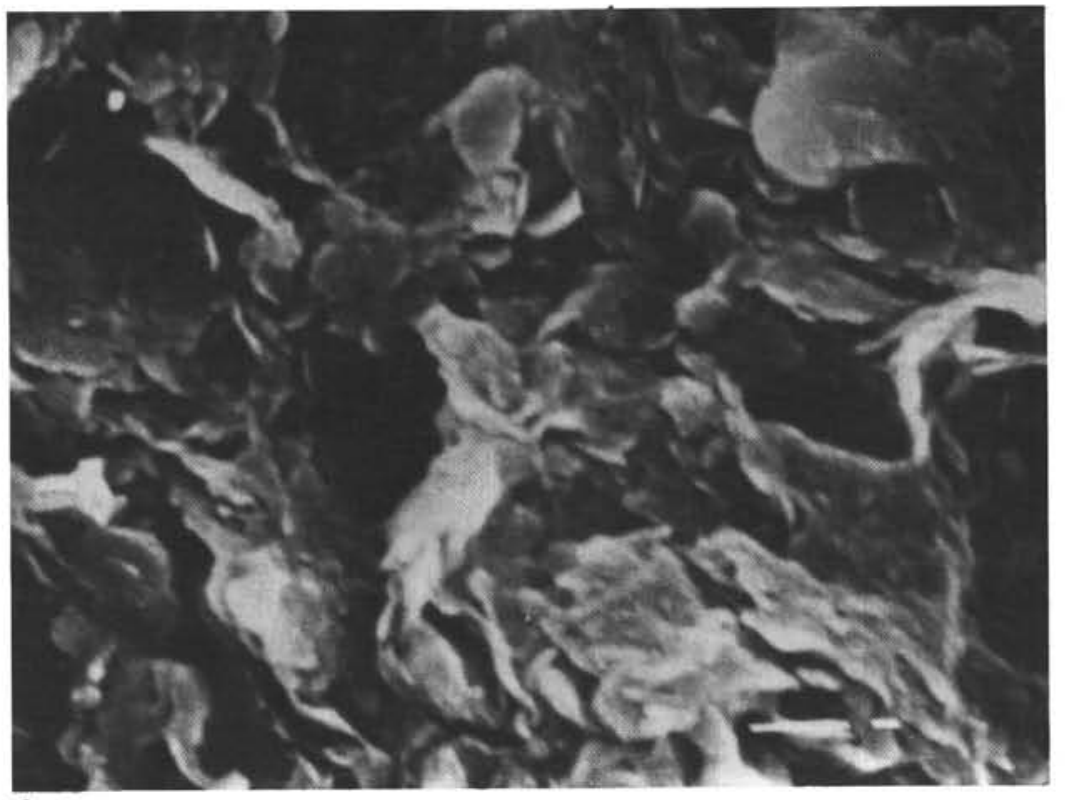

1

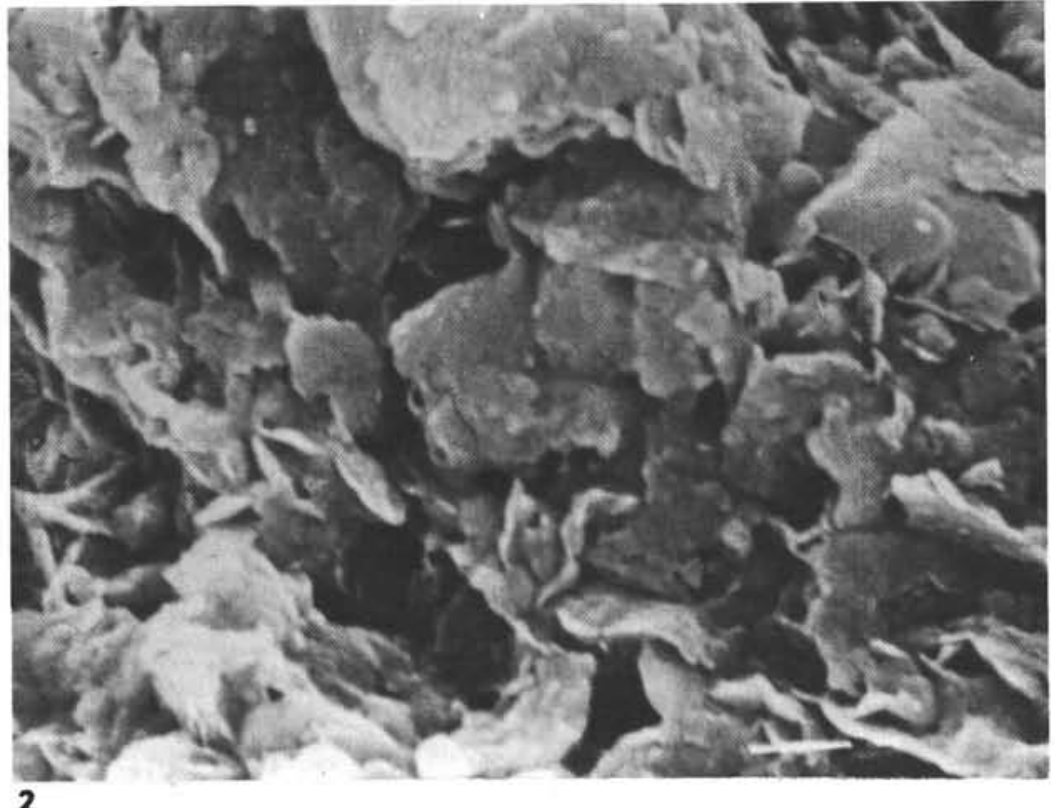

2

Plate 14. Sample 515A-25-2, 116-118 cm. 1. Large plates and coalesced domains lie in a pervasive linear FF pattern, interrupted by a few large and small EF-bridging structures; deformation of large EF-oriented plates forms circular, pitlike voids. 2. Small pits formed by deformed EF bridges between parallel plates create small voids. 